\title{
The Radiated Tortoise of Madagascar
}

\author{
J. O. Juvik
}

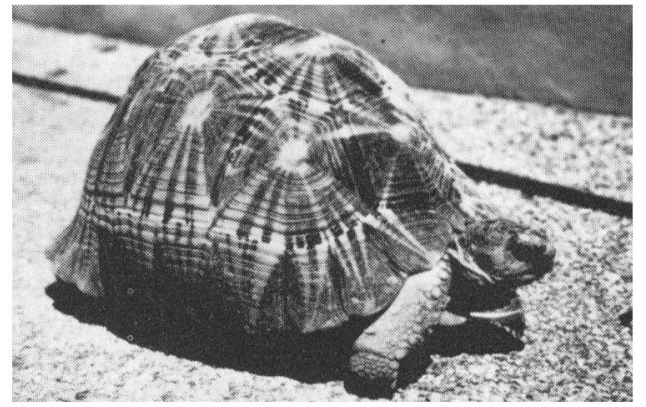

After a preliminary survey in $\mathbf{1 9 7 4}$ the author suggests that the outlook for the radiated tortoise in southern Madagascar is not entirely gloomy, thanks to traditional taboos on eating its flesh, improved government controls on exports, and import restrictions in other countries. Its future depends on the survival of some natural habitat; at the same time, he suggests, modern agricultural developments may be indirectly beneficial.

The most widely known of the endangered Madagascar reptiles is the radiated tortoise Geochelone radiata with its large, bulbous, beautifully marked shell. Recent research (5), however, suggests that its close relative Geochelone yniphora is much more critically endangered and in need of immediate conservation action. In a recent survey of the Malagasy tortoises (4) I have expressed some cautious optimism regarding the survival prospects for this species along with the other endemic forms Pyxis arachnoides and Acinixys planicauda. This paper summarises more specific observations on the status of the radiated tortoise gathered in August 1974 during the reconnaissance phase of a research project on the ecology of endangered Malagasy tortoises; the data presented here are of a preliminary nature.

In the arid south, where rainfall is erratic and averages less than $400 \mathrm{~mm}$. annually, the radiated tortoise inhabits xerophytic forests composed of weirdly formed, cactus-like Didierea plants. This vegetation type extends in a broad arc across southern Madagascar from near Amboasary to the vicinity of Morombe on the west coast, $175 \mathrm{~km}$. above Tulear (6). Within this general

TYPICAL TORTOISE

HABITAT Didierea forest near Ambovombe J. O. Juvik 
forest environment the tortoise appears to favour habitats dominated by low thornbush and grass cover, which apparently offer a better food supply than the dense Didierea thickets. It is a harsh and desolate land, sparsely peopled by proud and independent Antandroy and Mahafaly tribesmen who tend their herds of zebu cattle and are constantly struggling for survival against recurrent drought and food shortage. Both tribes consider $G$. radiata sacred, and a traditional taboo ( $f a d y$ ) prohibits eating them. Without this fortunate protection the species might have succumbed long ago. Occasionally the tortoises are kept as pets, housed with the village chicken flock, in the belief that their presence will ward off poultry diseases.

The map gives a preliminary summary of the tortoise's current distribution, including a qualitative assessment of exploitation levels. In 1950 Decary (3) gave the range of the tortoise as extending south-eastward from the Onilahy River to the Bay of Ranofatsy (within about $40 \mathrm{~km}$. of Fort Dauphin). Today it is rarely encountered east of the villages of Ambondro and Antaritarika, indicating an apparent range contraction of about $75 \mathrm{~km}$. The area between Ambondro and Amboasary still contains suitable natural habitat, so it may be reasonably concluded that collecting pressure emanating from Fort Dauphin has been responsible for the species's depletion in these adjacent areas.

Decary indicated the Onilahy River as the northern limit of the tortoise's range, but recently its presence north of the river has been confirmed by Blanc (pers. comm. 1971) who found it between the river and the Tulear Highway. The species has also been reported to occur 'less commonly' between Tulear and Morombe (1). At the present time the status of the tortoise north of the Onilahy River can be characterised as severely depleted, and similar to the situation near Fort Dauphin. Its elimination from areas adjacent to these major port cities reflects the legacy of commercial exploitation during the 18th and 19th centuries, when large numbers where shipped to the nearby Mascarene Islands for food.

The tortoise is still relatively common in the more inaccessible areas of the Mahafaly and Karimbola Plateaus and it also occurs in the Lake Tsimanampetsotsa Natural Reserve. Baudy's erroneous statement (1969) that $G$. radiata no longer occurred west of Ampanihy, was apparently based on inadequate field data (2).

Present exploitation of $G$. radiata, in the form of subsistence hunting or quasi-commercial† collecting for resale, appears to be restricted primarily to areas along the major highway (National Route 10) connecting Fort Dauphin and Tulear. The highway fortunately skirts the core range of $G$. radiata, except in the region extending roughly from Ambondro to the area north of Beloha, where it penetrates deeply into prime tortoise habitat. In this area autobuses and taxis often stop to allow tortoises on the road to be collected by passengers, usually the less tradition-bound town dwellers, who choose to ignore both the traditional taboos and existing conservation laws. The important point, however, is that collecting seems to be largely unorganised and based on random opportunity, rather than a systematic, full-time operation.

$\dagger$ The term quasi-commercial is used to imply that any current collecting for resale (as either food, varnished shell curios, or for the animal trade) is generally unorganised and intermittent. 


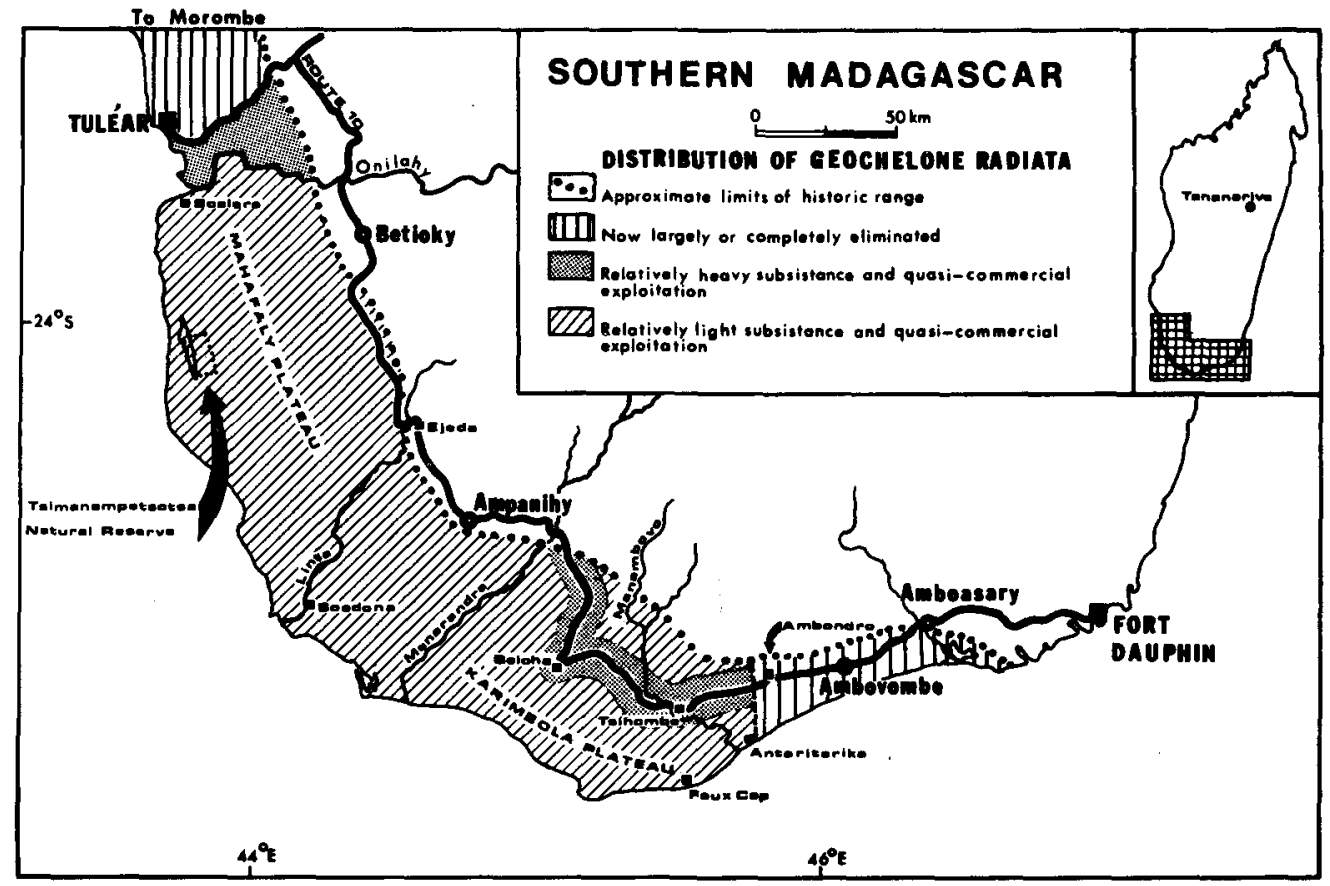

After heavy rain tortoises may still be encountered along the highway at the rate of up to 1 per kilometre - a high density, despite years of heavy collecting, that bodes well for the populations in more inaccessible areas where traditional taboos remain in force.

The export of radiated tortoises for the pet and animal trade has declined substantially in the past few years, as a result of both better enforcement of export restrictions by the Malagasy Government, and effective prohibitions or controls on imports into the United States (Endangered Species Act), Britain and other European countries. While some limited export (both legal and illegal) continues at present, this can be expected to diminish further as more nations adopt and enforce endangered species legislation.

The short term outlook for G. radiata warrants some optimism, insofar as substantial areas of its current range remain relatively free of heavy exploitation or habitat destruction. Declining export trends are also encouraging. The long-term prospects for the species are more difficult to assess. Future socio-economic and agricultural developments in southern Madagascar can be expected to exert both positive and negative influences on the native biota. Large-scale irrigation schemes, for example, are inevitable and essential to improve living standards. Such projects, however, may actually benefit natural ecosystems, because the resultant concentrations of human population and the increases in farm productivity and efficiency could eliminate some of the marginal subsistence farming and grazing activities which cause widespread habitat deterioration and erosion. The implication here is that international assistance for wildlife conservation should not overlook the indirect benefits derived from sound economic and agricultural development projects. The future of Geochelone radiata, is after all, ultimately tied to the future of human occupation and land use in southern Madagascar. 


\section{Acknowledgments}

Research in southern Madagascar was supported in part by a grant from the New York Zoological Society. I would like especially to thank Mr J. M. Andriamampianina, Director of the Département des Eaux et Forêts Republic of Malagasy, for his support of my research activities and continuing conservation efforts on behalf of the Malagasy tortoises.

\section{References}

1. ALBIGNAC, R. 1968. Unpublished reference cited in IUCN Red Data Book Vol. 3.

2. BAUDY, R. E. 1970. Int. Turtle \& Tortoise Soc. Jour., Jan.-Feb., pp. 19-25.

3. DECARY, R. 1950. La Faune Malgache. Paris, pp. 88-91.

4. JUVIK, J. O. 1975. Defenders of Wildlife, 50:172-3.

5. JUVIK, J. O. and BLANC, C. P. 1974. Animals, 16(4) 148-153.

6. ROBEQUAIN, C. 1958. Madagascar et les bases dispersées de l'Union française. Paris.

\section{Wildlife Protection in China}

Two factors have greatly helped China's wildlife in the last decade, says Norman Myers, in the July International Wildlife: the Government's decision in the 1960s to slow down the development of new agricultural land, concentrating rather on improved yields from land already cultivated, and the considerable success achieved in slowing down the population growth rate. The Chinese, he says, now show great concern for their wildlife, and the giant panda, whose range had shrunk enormously, is a symbol of national pride; no Chinese would think of killing one, and its only enemy is the leopard. Its stronghold is the Wang-Lang Reserve in western Szechwan, almost 80 square miles of ravines and forest in the Min Shan Mountains; even outside the reserve it can maintain itself, for it poses no threat to livestock or people, prefers the most inaccessible terrain, and is almost never seen.

All nine species of deer in China have been greatly reduced and are threatened to some extent, but all are now protected with specific sanctuaries for each. Moreover, Norman Myers believes that the Government has succeeded in debunking the myth of the aphrodisiac properties of powdered deer antlers and rhino horn, certainly among young people. Until 1960 musk deer were relentlessly hunted for the musk, but a method of removing this from the animals without killing them has been devised, and musk deer have now increased to the point where limited hunting is allowed.

To protect the Przewalski horse the Government has encouraged nomadic herdsmen to use artificial waterholes for their domestic stock, leaving the natural ones undisturbed for the horses, which cross into China from Mongolia in the winter. This policy also helps the kiang, the Asiatic wild ass, now confined to Tibet but believed to be increasing in numbers.

The policy of eliminating tigers, which persisted until the mid-1960s has been 'partially reversed', and a refuge system is being planned; the tiger is partially protected; the Siberian tiger is fully protected, and treeplanting in the north-east is creating habitat for prey species. Leopards are fairly common, but pelts are going out in some numbers to Hong Kong dealers-a figure of 3000 skins seems likely. Clouded and snow leopard are protected except where individual animals take livestock.

The Chinese endangered species list, which lists 32 species and subspecies is being revised and more species added. 